RESEARCH PAPER

\title{
The Philippine tobacco industry: "the strongest tobacco lobby in Asia"
}

K Alechnowicz, S Chapman

Tobacco Control 2004;13(Suppl II):ii71-ii78. doi: 10.1136/tc.2004.009324

See end of article for authors' affiliations .....................

Correspondence to: Professor Simon Chapman, School of Public Health, Room 320B Edward Ford Building, A27, University of Sydney, Sydney, NSW 2006 Australia; simonchapman@health. usyd.edu.au
Objective: To highlight revelations from internal tobacco industry documents about the conduct of the industry in the Philippines since the 1960s. Areas explored include political corruption, health, employment of consultants, resisting pack labelling, and marketing and advertising.

Methods: Systematic keyword Minnesota depository website searches of tobacco industry internal documents made available through the Master Settlement Agreement.

Results: The Philippines has long suffered a reputation for political corruption where collusion between state and business was based on the exchange of political donations for favourable economic policies. The tobacco industry was able to limit the effectiveness of proposed anti-tobacco legislation. A prominent scientist publicly repudiated links between active and passive smoking and disease. The placement of health warning labels was negotiated to benefit the industry, and the commercial environment allowed it to capitalise on their marketing freedoms to the fullest potential. Women, children, youth, and the poor have been targeted.

Conclusion: The politically laissez faire Philippines presented tobacco companies with an environment ripe for exploitation. The Philippines has seen some of the world's most extreme and controversial forms of tobacco promotion flourish. Against international standards of progress, the Philippines is among the world's slowest nations to take tobacco control seriously. a 1995, Philip Morris International's (PMI) advertising agency, Leo Burnett, summarized the Philippine situation with the slogan "There can't be a better time"1 for the tobacco industry. According to the agency, international antitobacco activists had nominated the Philippines as having the strongest tobacco lobby in Asia. ${ }^{2}$ By 1996, the Philippines ranked first in sales for PMI's Asian region ${ }^{3}$ and continued growth led to the establishment of a US\$300 million manufacturing facility in the country which commenced production in $2003 .{ }^{4}$

The Philippines (population 80 million) is the 15th biggest consumer of cigarettes in the world ${ }^{5}$ and the largest consumer among the Association of Southeast Asian Nations (ASEAN). ${ }^{6}$ Some $54 \%$ of adult men and $11 \%$ of adult women smoke ${ }^{7}$ with overall adult smoking prevalence being the fourth highest among ASEAN countries. Tobacco use among Filipino youth ( 18 years or less) is high, with approximately $37 \%$ of young men and $18 \%$ of young women smoking on at least a monthly basis. There has been a $33 \%$ increase in the prevalence of having ever smoked since $1995 .{ }^{8}$ Alarmingly, almost one fifth of young Filipinos begin smoking before age 10.8 A 1999 government white paper on smoking calculated that two Filipinos die every hour from tobacco use. ${ }^{9}$

Cigarette prices in the Philippines are low, with the price of Marlboro being the second lowest for all ASEAN nations. ${ }^{10}$ The cigarette market has been dominated by menthol brands for several decades, ${ }^{11}$ although non-menthol volume has been steadily improving in recent years. ${ }^{12}$ La Suerte Cigar and Cigarette Company and the Fortune Tobacco Company (FTC) have been the two leading producers, and have had licensing agreements with PMI and RJ Reynolds (RJR) respectively. FTC commands a $67 \%$ market share, while La Suerte holds a $25 \%$ share. $^{13}$

Unlike other Asian nations, the Philippines is a highly Christian country, with approximately $80 \%$ of the population being Catholic. English is spoken widely, with a recognisably American accent. There has been a strong US presence in the Philippines since the American colonial period from 1901 until 1946. ${ }^{14}$ This presents a rare cultural consistency between an Asian nation and the Anglophone tobacco transnationals.

Poverty and unemployment remain the country's gravest economic problems. ${ }^{15}$ Gross national income is $\$ 1020$ per capita, and approximately $28 \%$ of people live below the national poverty line. ${ }^{16}$ Economic problems are higher in rural areas where some $55 \%$ live in poverty. ${ }^{17}$

For many years, the Philippines was governed by an administration with a global reputation for corruption, particularly during the presidency of Ferdinand Marcos (1972-1986). The commercial necessity of using contact men to facilitate cronyism in conducting business was acknowledged in an early Philip Morris document. ${ }^{18}$ In the first paper to report on revelations from the tobacco industry's internal documents, this paper examines the conduct of the tobacco industry in this political and commercial environment, highlighting tactics and episodes illustrative of the companies' conduct in thwarting tobacco control.

\section{METHODS}

The evidence presented was located from internal tobacco industry documents located through searches conducted on the Master Settlement Agreement websites between December 2003 and March 2004. ${ }^{19}$ Search words included Philippine geographical terms as well as the names of local tobacco companies and organisations. To facilitate systematic analysis, the 5958 documents and related metadata collected

Abbreviations: AFTA, ASEAN Free Trade Area; ASEAN, Association of Southeast Asian Nations; BAT, British American Tobacco; B\&W, Brown \& Williamson; ETS, Environmental Tobacco Smoke; FTC, Fortune Tobacco Company; PMI, Philip Morris International; RJR, RJ Reynolds 
from the searches were incorporated into a database. The results were sorted by date and evaluated according to their degree of relevance to a concern to examine industry conduct in the Philippines relevant to tobacco control. The final analysis is based on 164 documents identified as having most relevance to this topic. A detailed search strategy explanation including a list of search terms is available at http://tobacco.health.usyd.edu.au/site/gateway/docs/pdf/ Philippines Search Strategy.pdf. Lack of access to British American Tobacco documents from the Guildford depository is a limitation..$^{20}$ A further limitation is the lack of documents found from local tobacco companies such as FTC and La Suerte, so the paper is best read as an overview or primer to a detailed history of tobacco industry conduct in the country.

\section{RESULTS}

\section{Political corruption}

The Philippines has long suffered a reputation for endemic political corruption. ${ }^{21}$ Evidence spanning 30 years (19621992 ) reveals that foreign tobacco companies sought to work within this operating environment. A 1962 PMI document noted that key political figures might be paid off in order to release tobacco being withheld from sale: "Two parties approached me yesterday and informed me that for P6M or $\mathrm{Pl}$ per $\mathrm{lb}$. they could induce Senators and perhaps the President to release the tobacco". ${ }^{22}$ Internal PMI correspondence from 1963 noted that "[c]orruption, bribery, smuggling and dirty politics are worse than anywhere else and continues for the benefit of officials who want to get rich quick" ${ }^{\prime 23}$

With the help of the USA, martial law was established in 1972. Collusion between state and business routinely featured the exchange of political donations for favourable economic policies. ${ }^{21}$ Consequently, the state had trouble controlling the erratic economic policies developed by commercially sponsored politicians.

The tobacco industry was well aware of the economic advantages of cronyism. A Lorillard executive highlighted this in 1973: "Again the government has postponed the announced tax increase... It is entirely possible that there will be no increase as the implementation dates have now twice been delayed and according to reliable sources will be put off again for a price... the government has been bought off twice and it is possible for it to happen again as the manufacturers stand to lose considerable revenue if the bill is enacted". ${ }^{24}$

The general manager of the FTC, business tycoon Lucio Tan, was able to evade and hinder tax changes through his long established relationship with the Cabinet. Tan had close ties with the Marcos regime and beyond, where embedded cronyism assisted him in instilling a protectionist policy for his company. Tan was said to have "gotten his way" ${ }^{\prime 25}$ by convincing Congress to stay with a two tiered ad valorem tax system $^{26}$ which gave FTC a pricing advantage over its competitors. ${ }^{27}$

In 1986, PMI secured a "leading role in the Philippine Chamber of Commerce" through the appointment of Richard Snyder, a PMI executive, as the Chamber's chairman. PMI boasted that its staff held "key positions in a wide array of international organizations" that could be of future assistance. $^{28}$ The Ramos administration was elected in 1992 with only $32 \%$ of primary votes. It was "rocked by scandals, corruption and slow decision making"12 and continued the tradition of cronyism. Ramos, in an attempt to spark the national economy, developed a bill to breakdown large monopolies including the tobacco sector. ${ }^{29}$ Publicly, tobacco corporations and other targets gave "wholehearted lip service" but then surreptitiously called upon their favourite congressmen in an attempt to limit the bill's effectiveness. $^{29}$

\section{Licensing agreements}

In 1955, PMI established a licensing agreement with local tobacco manufacturer La Suerte Cigar \& Cigarette Company. Its flagship brands, Marlboro and Philip Morris, were produced at La Suerte's manufacturing plant until PMI chose not to renew its contract with La Suerte, which expired on 31 December 2002. Production has now commenced at PMI's new 25 hectare manufacturing plant, the company's biggest investment in Asia to date. The plant will reap the benefits of the ASEAN Free Trade Area (AFTA). Established in January 1992, the AFTA aims to eliminate tariff barriers for ASEAN on a wide range of products traded within the region, including tobacco. ${ }^{30}$

In 1974, RJ Reynolds signed a contract with local manufacturer, Fortune Tobacco Company (FTC) "to manufacture RJR name brand cigarettes in the Philippines". ${ }^{31}$ According to BAT, through "unfair and discriminating laws to favor Fortune" Lucio Tan was able to command the highest cigarette market share in the Philippines for many years. ${ }^{12}$ FTC was able to maintain this share through discriminatory pricing advantages that allowed its international brand names to be classified as local brands thus reducing tax duties. In contrast, PMI's international brand names manufactured by La Suerte were classified as imported brands and subject to higher taxes. Tax avoidance by manufacturers extended to the establishment of "dummy marketing companies" ${ }^{\prime 2}$ in the 1990s as the computation of the excise tax levied was based on a percentage of the exfactory price. These dummy companies were the first link in the distribution chain and minimised price increases. ${ }^{32}$

\section{Obfuscating health problems}

The Philippine tobacco industry worked in step with its international counterparts to publicly repudiate the links between smoking and disease. In 1983 the Minister for Health, Jesus Azurin, stated that smoking was the "fifth cause of mortality in the Philippines"133 and research published in the Philippine Journal of Oncology in 1984 concluded that smoking was the single most important contributory factor in more than $80 \%$ of all lung cancers. ${ }^{34}$ Yet, as elsewhere in the world, ${ }^{35-38}$ the tobacco industry sought to deny and obfuscate the health hazards associated with smoking. During the 1970s and 1980s, Domingo Aviado, a Filipino pharmacologist resident in the USA, spoke out against reports claiming associations between smoking and deleterious health effects. During this period, cigarette consumption was steadily rising. ${ }^{13}$ A journalist from the Philippine Daily Express stated that Aviado was "neck-deep in research, trying to disprove the claim of the U.S. surgeongeneral" against smoking and that "Dr. Aviado may yet prove that cigarettes are not only safe but may actually be good for the health". ${ }^{39}$

Aviado, whom Marcos had awarded his presidential "most distinguished Filipino abroad" award in $1975,{ }^{40}$ was also a member of the American Heart Association. He argued that Filipinos were less cancer prone than other communities, ${ }^{41}$ and had a lower risk of developing coronary heart disease than US citizens. ${ }^{42}$ His views were published in local newspapers in 1975 with headlines such as "Doctor debunks link of smoking to hypertension" 43 and "New light shed on smoking perils". ${ }^{42}$ Aviado was paid US\$22 685.00 in consulting fees from the tobacco industry in 1975, the largest amount to any of eight consultants. ${ }^{44}$

Through "courtesy of...Philip Morris International", Aviado spoke at a 1980 tobacco forum organised by the Philippine Virginia Tobacco Administration, advising that "in 
the event that I will testify before the committees in the Batasang Pambansa [National Assembly], I have prepared ...key arguments against the Bill 605 which is relating to labeling cigars and cigarette packages... The health problems of Filipinos are different from the health problems of Americans and Europeans...there is no scientific basis for labeling tobacco products that smoking is dangerous to the health of Filipinos" ${ }^{45}$ As recently as 1994, PMI commissioned the advertising agency, Leo Burnett, to propagate "studies that point to other possible causes of lung cancer". ${ }^{1}$

\section{Tar and nicotine}

In the same year Aviado was publicly disputing any causal link between smoking and deleterious health effects, local cigarettes in the Philippines were found to contain $8 \%$ more nicotine and 76\% more tar than imported brands. ${ }^{46}{ }^{47}$ Despite this, advertisements from the Philippine Tobacco Board, in conjunction with the Department of Trade, stated the opposite in a public advertisement: "Internationally, the Philippine grown tobacco...is possibly the only safe, noncancer producing tobacco because of the very low tar and nicotine content and because Philippine grown tobacco burns completely, avoiding the formation of hazardous hydrocarbons." ${ }^{\prime 48}$

In 1981 Philip Morris noted it had been able to influence government to keep tobacco yield information off packs: "There is a Bill before the Philippine Government which calls for cigarette manufacturers to publish tar and nicotine numbers on cigarette packs. So far we have been able to delay the passing of this Bill." ${ }^{\prime 4}$

\section{Environmental tobacco smoke consultants}

As in other parts of Asia and the world, ${ }^{50-53}$ the industry recruited and briefed apparently credible scientists in the Philippines who could then be available to testify on ETS in legislative, regulatory, or litigation proceedings to defend the industry's position. ${ }^{54}$ PMI's environmental tobacco smoke (ETS) programme aimed "to put ETS in perspective and maintain social acceptability of smoking by dispelling the misconceptions about ETS and promoting tolerance and courtesy"..5 By October 1989, two initial consultants were recruited for the Asian ETS Consultants Project. ${ }^{54}$ Dr Benito Reverente was a member of the WHO Occupational Health Panel and a Lecturer at the University of the Philippines, and had excellent Asian connections. Professor Lina Somera, Head of Public Health in the University of the Philippines, was also recruited. ${ }^{56}$ PMI agreed to pay Reverente and Somera $\$ 600$ per day for their consultancy work. Doctors who the tobacco industry considered to be of lower stature were "politely discouraged" from becoming consultants, and instead assisted with consultant recruitment through their contacts. ${ }^{57}$

At the request of several supporting companies, ${ }^{54} \mathrm{John}$ Rupp from PMI's legal firm Covington and Burling recruited two additional Philippine consultants. Dr Camilo Roa Jr, a well known pulmonary physician, was undertaking research that PMI believed could be used to promote the insignificance of ETS in the development of respiratory disease. ${ }^{54} \mathrm{Dr}$ Luis Ferrer, a prominent architect, was also recruited to bring practical knowledge to the project regarding building design and ventilation, and how these could effectively deal with indoor air pollutants such as ETS. Ferrer had extensive ties with the government due to his position as Director of Health Infrastructure Services for the Ministry of Health. ${ }^{54}$ In order to increase the stature and credibility of the consultancy group, it was suggested they accept and solicit research assignments from a variety of sponsors, including government bodies. ${ }^{58}$
Reverente claimed that ETS was rarely trapped indoors and that outdoor air pollution in cities overwhelmed the comparatively miniscule contribution to the indoor environment made by ETS. ${ }^{57}$ Research was also conducted to test indoor air, pointing to indoor air pollution sources unrelated to ETS. ${ }^{58}$ A newspaper article asserted, "[i]f you are experiencing indoor pollution and blame environmental tobacco smoke (ETS) for your predicament, you are looking at the wrong suspect. A number of scientific studies have concluded that inadequate ventilation is most often the real culprit, according to Asian Tobacco Council, an organization of individuals and companies associated with the tobacco industry in the Asian region". 59

\section{Packaging}

The saga of delays in introducing pack warnings perhaps best illustrates the power the Philippine tobacco industry had in influencing government policy. While pack health warnings first appeared on US packs in 1966, Philippine citizens had to wait nearly 30 years to read health warnings. During the 1970s, the government developed a bill that would require cigarette manufacturers and importers to print "Caution: Smoking tobacco may be hazardous to your health" ${ }^{60}$ on packs. By 1981, the National Assembly had still not approved health warning labels, ${ }^{61}$ and industry documents from the 1980s argue that warning labels on packs were not required. ${ }^{62}{ }^{63}$ In a public hearing addressing cigarette regulatory legislation, fear was expressed by the head of the National Tobacco Administration that a health warning label could adversely affect the tobacco industry. An FTC representative stated that if labels were to be required, the warning should be toned down to "smoke at your own

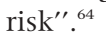

In 1991, proposals for national legislation to introduce health warnings resurfaced. PMI stated "we believe that in quiet discussion with government officials and L.S. [La Suerte], we will be able to negotiate the placement of the proposed warning statements". ${ }^{65}$ The effectiveness of Philippine tobacco industry lobbying against government proposals was seen as exemplary within the industry. In 1993, a PMI USA executive requested PMI Asia to share information on how the Philippine industry had influenced government to push through a "reasonable warning label regime". ${ }^{65}$ The House of Representatives had passed The Consumer Act which, as advocated by the industry, ${ }^{66}$ required that all packs carry a health warning on one side panel from 1 July 1994. ${ }^{67}$ The bland notice read "Warning: Cigarette Smoking is Dangerous to Your Health" ${ }^{68}$

An internal document from 1994 highlighted industry concerns regarding front panel warnings: "Government required warnings placed on the largest packaging panel, often called the front and/or back, are the biggest marketing threat to all of us in Asia ... Our final communication vehicle with our smoker is the pack itself. In the absence of any other marketing messages, our packaging...is the sole communicator of our brand essence. Put another way-when you don't have anything else-our packaging is our marketing." ${ }^{\prime \prime 9}$

In 1994, the Philippines Industry Association commenced a lawsuit against regulation requiring that the side panel health warning be replaced by back and front notices covering $25 \%$ of both panels. ${ }^{70}{ }^{71} \mathrm{~A}$ decade later, side panel warnings are still in place, and will continue to occupy not less than 50\% of one side panel until 30 June 2006. Commencing 1 July 2006, health warnings will be located on the front panel of every tobacco product package and occupy not less than $30 \%$ of these panels. Four rotating health warnings were implemented on 1 January 2004 as part of the Tobacco Regulation Act of 2003, and must each equally appear within a 24 month time period. ${ }^{72}$ 
The Philippine saga contrasts starkly with some Asian countries that have advanced tobacco control policies. Brunei Darussalam imposed four rotating warnings on the front of packs in 1991. Hong Kong has six rotating health warnings that must appear on the front and back of packs. ${ }^{73}$ Thailand has front and back warning labels, where every cigarette pack and carton must display one of 11 rotating warnings. ${ }^{13}$ Singapore has not only had four rotating front warnings since 1993, but these became pictorial on 1 August 2004. ${ }^{74}$ The Philippines has similar tobacco control policies to Indonesia, Malaysia, and Cambodia, where side warningsthe most favoured industry position-are presently utilised.

\section{Marketing and advertising}

Philippine tobacco manufacturers operate under some of the world's most laissez faire advertising conditions. In 2000, Fortune Tobacco alone spent $\$ 17.9$ million to promote its cigarettes across all media, making the company the country's eighth largest advertiser. This advertising expenditure was more than 300 times the size of the public information and education budget of the Philippine Department of Health. ${ }^{75}$

The Philippines has seen some of the world's most extreme and controversial forms of tobacco promotion flourish in this climate. In recent times, to capitalise on the religious faith of the Filipino population, the Virgin Mary has featured on promotional calendars for Fortune Tobacco, and one brand was named "Lord 100s". ${ }^{76}$ Near naked women and those in sexually provocative poses have featured in advertising. ${ }^{.7-79}$ Many promotions targeted the widespread poor by giving away expensive prizes such as cars, electrical goods, and cash. ${ }^{80}$ Fi Fortune Tobacco even has a brand called "Hope". Flagrant Americanisation of smoking has abounded. US military bases were supplied with imported US cigarettes. These rapidly infiltrated the community, laden with aspirational appeal as westernisation became juxtaposed with wealth. ${ }^{82}$ The industry capitalised on this appeal. In the early 1970s, it was noted that manufacturers refrained from printing "Made in the Philippines" on packs as required by law, and instead stated: "These cigarettes are made from the finest tobacco flavor imported from the U.S.A.". ${ }^{83}$ A Brown \& Williamson $(\mathrm{B} \& W)$ report claimed that Lucio Tan was exporting locally made Champion and smuggling it back in as "blue seal" (local term for imported cigarettes from the USA), selling it at a higher price and giving it an imported image. ${ }^{84}$

In the early 1980s more women, especially college and university students, were starting to smoke. ${ }^{85}$ The proportion of young women who tried smoking doubled from $17 \%$ in 1994 to $30 \%$ in $2002 .{ }^{86}$ As has been their practice throughout the world, companies interested in expanding their market have sought to target promotions at women. Campaigns particularly emphasised the notion of slimness, resulting in the utilisation of cigarettes as a putative hunger suppressant. $^{79}{ }^{82}$ The Virginia Slims concept was used to appeal to young women, and projected a slim, "modern, contemporary, International, American image". ${ }^{87}$ Virginia Slims, "the slimmer cigarette with natural menthol women like" entered the Philippine market during a fashion show at the Manila Polo Club in 1976. Ads for the brand carried a picture of a "smiling, slender girl in a slimming dress, holding a cigarette". $^{\prime 88}$

In 1995, the Department of Health united with health advocates and citizen groups to support effective tobacco control legislation. ${ }^{75}$ Since then, most legislative proposals seeking to regulate advertising have been thwarted, primarily in the Philippines House of Representatives where many legislators represent tobacco growing regions. ${ }^{75}$ The Tobacco Regulation Act of $2003^{72}$ purports to regulate the sale and use of tobacco nationwide, and will ban all forms of tobacco advertising in the media by 1 July 2008, including the sponsorship of cultural and sporting events and educational programmes by the tobacco industry. However, remarkably, tobacco advertisements will still be allowed on radio and television until 1 January 2007 and in cinemas and outdoors until 1 July 2007. All mass media advertising will be prohibited by 1 July 2008, except inside the premises of point-of-sale retail establishments. ${ }^{72}$ There are few nations where tobacco advertising has been allowed to run across all media for this long.

\section{Youth}

By 1975, B\&W had begun to realise the implications of continuing to make explicit references to their interest in marketing to youth, even in internal correspondence. It determined that it should eradicate the use of explicit references to young smokers and created a code to be adhered to in all written correspondence, as if anticipating that such material might one day fall into the hands of those who could use such references against them: "In the future when describing the low-age end of the cigarette business please use the term "young adult smoker" or "young adult market" ${ }^{89}$ As elsewhere in the world, this code language was rapidly adopted by other companies and was used extensively throughout Philippine documents, revealing a sustained preoccupation with marketing campaigns directed at the young.

By 1983, the popularity of Marlboro among youth exceeded that in the adult population. Marlboro then held a 35-40\% share in Metro Manila but "more than 50\%" in high schools. ${ }^{90} \mathrm{~A}$ B\&W executive, on a trip to the Philippines in 1984, was told that Marlboro was smoked by "approximately $90 \%$ of students". ${ }^{91}$ In a 1989 court testimony for the American Cancer Society, it was stated that Japan Tobacco Incorporated was running commercials for Mild Seven cigarettes in the Philippines using teenage models and a slogan "It's All Right" to smoke. ${ }^{92}$

During the 1990s, the Philippine Tobacco Institute produced a voluntary code typical of those produced by its global counterparts which stressed that advertising and promotions were only to be directed at existing adult smokers and never directed at minors. ${ }^{93}$ Despite this ostensible posturing in corporate responsibility, companies recognised the potential to capitalise upon youth impressionability through advertising: "[T]otal commitment to the quantum enhancement of the advertising and promotions...will win the battle for the hearts and minds of our primarily young adult target group." ${ }^{94}$

"Advertising" "portray a younger, masculine image". ${ }^{95}$ The 1993 Philippines Brand Plan suggested PMI "Use a mix of TVC's [television commercials] with cowboy/country themes that will appeal more strongly to young adult viewers via: portrayal of younger cowboys as heroes; updated music tracks; spot placements in TV programs with a significant young adult profile." 95

The Philippine market with its unrestricted advertising presented the industry with the opportunity to capitalise on the "young adult appeal of movies", 95 enabling them to "present the drama and grandeur" of their product heroes "in a more compelling manner". ${ }^{95}$ Marketing strategies included young adult talents and lifestyle situations. ${ }^{95}$ Roving film vans aired free movies nightly in localities where television penetration was low. ${ }^{95}$ This strategy had been employed since the 1970s when trucks equipped with movie projectors and loud speakers targeted isolated towns, screening free films while plugging their cigarettes, distributing samples, and making special spot sales. ${ }^{96}$ 
Youth heroes were employed by the industry. Richard Gomez was a handsome athlete and actor who was not only spokesman for Fortune Tobacco Company, ${ }^{9}$ but was appointed Cabinet level advisor for youth sports under the Estrada administration. ${ }^{82}$ Gomez was actively involved in youth development programs projecting an image of fun, glamour, athleticism, and popularity ${ }^{9}$ to Filipino youngsters.

In 1992, the Philippine Department of Health (DOH) launched the anti-smoking campaign 'Yosi Kadiri' (Filipino slang for "cigarettes are disgusting"). The campaign sought to decrease smoking among children, and attempted to counter the handsome cowboy and sporting images of smokers promoted in tobacco advertising. ${ }^{75}$ A cartoon mascot, Yosi Kadiri, was the campaign's mascot, and appeared in the media, coupled with movie and television personalities. ${ }^{9}$ The campaign was considered quite successful, although government funding rapidly depleted. During this time, PMI commissioned the Leo Burnett advertising agency to counter the campaign. In 1995, a Leo Burnett memo boasted that one of their accomplishments for 1994 was to help "neutralize the impact of DOH 'Yosi Kadiri' campaign". ' At the same time, Leo Burnett projected tobacco industry support for legislation aiming to curb juvenile smoking.'

As elsewhere in Asia, ${ }^{97}$ the industry publicly projected support for anti-tobacco initiatives targeting juvenile smoking. "We strongly believe youth should not smoke and are committed to leading and supporting initiatives which address this concern." "the most important catalyst of, and most active participant in, programs to address the issue of under aged smoking". ${ }^{99}$ In 1998, PMI supported an education programme in the Philippines that aimed to strengthen the character of youth so that they could better handle peer pressure on a variety of lifestyle issues, including smoking. ${ }^{100}$ The program, entitled "I am strong", was implemented in just six Manila high schools by $1999 .{ }^{99}$

\section{Sponsorship}

Sponsorship in the Philippines enabled companies to capitalise extensively on their marketing freedom. In 1974, Salem, manufactured by FTC, sponsored a television programme about the Philippine First Lady, Imelda Marcos. ${ }^{101}$ By 1980, PMI had implemented a Child and Maternity Welfare programme which "further strengthened PM's corporate image in the Philippines". ${ }^{102}$

Sponsorship of sports, the arts, and cultural events frequently targeted "the key young adult segment". ${ }^{103} 1973$ saw FTC sponsor the Miss Republic of the Philippines competition, ${ }^{104}$ while La Suerte initiated the "Marlboro GG [Game of the Generals] Freedom Games". This "thinking sport" was popular among college students, and projected the Marlboro image through giant advertising billboards constructed to aid spectators in following the games. ${ }^{105} 106$

The music industry gave companies further opportunity to exploit their marketing freedom. In 1983 it was noted "Mr Tan is...sponsoring a Filipino Music concert, granting admission for empty packs of Hope and More"..$^{90}$ During the 1990s, sponsorship of music radio programmes gained popularity. Marlboro music sponsorship had a stated objective to "Capitalize on the "Marlboro No. 1 Music" radio program, ...(Manila's leading young adult station) to build brand equity in the young adult segment". ${ }^{95}$ Similarly, the PM Jazzshow radio programme was classified as the most popular progressive programme for 1993. It provided a platform for PM to "capitalize on strong listenership as an effective opportunity for stronger brand reach and exposure in young adult segment". ${ }^{95}$

Sporting sponsorship was especially insidious, implying that smoking and fitness mixed, ${ }^{107}$ thus providing a lucrative chance for companies to captivate youth. "If there is any sports promotion that would be worth doing in the Philippines, Basketball would be it". ${ }^{108}$ Basketball was the nation's most widely watched and most widely played sport. PMI organised an NBA All-Star Tour in $1988,{ }^{108}$ and by 1994, the Philippine Basketball Association (PBA) agreed to exclusive sponsorship rights for PMI. ${ }^{109}$ The annual Marlboro PBA showdown had a stated objective that "prime emphasis must...be focused on the young adult segment". ${ }^{95}$ The showdown exported elite basketball heroes to towns outside metro Manila, ${ }^{109}$ thus gaining wider reach.

As in other nations, tobacco companies targeted youth through motorsport. This sport provided the industry with another important opportunity for strengthening appeal to the key young adult segment whose predispositions could be directly addressed by the excitement and action of motor racing. ${ }^{103}$

Sports sponsorship targeted youth at all levels of society. Upmarket sporting events such as "PM Golf Classic Series" promoting PM 100's appealed to Class $\mathrm{AB}$ young adults. ${ }^{95}$ In contrast, a report noted that the 23 day Marlboro bicycle tour "inspires poor, young men. It gives them hope of making it big, it answers their dreams". ${ }^{10}$

\section{Research}

Market research in the Philippines included smokers aged less than 18 years. B\&W explicitly stated their consumer research would comprise of "menthol smokers" 16 years of age and above to understand brand usage, attitude, and image. ${ }^{111}$ In 1984, B\&W undertook an extensive "Target Market Profile Study". Its purpose was to profile young Filipino males between the ages 15-19 for a proposed new brand, Hollywood. Information regarding leisure activities, music preference, media usage, and smoking habits was collected from 800 participants to assist the brand launch. It was found that "[a]wareness of any promotional activity, at $91 \%, \ldots$ was generally higher among the younger (1524) and lower socio-economic class (C and upper D) respondents". ${ }^{112}$

Market research for Marlboro Lights found that 15-24 year olds had the highest advertising awareness, highest rate of trying, highest rate of purchase, and occasional usage. Intense promotional campaigns resulted in high awareness: "Television was a more significant source of awareness for young smokers... In-store display was more likely to raise awareness of younger smokers." Indeed, 82\% of awareness came from TV for the youngest age group researched, and $74 \%$ of the youngest age group tested ever tried Marlboro Lights. ${ }^{113}$

\section{Jump boys}

In most of Asia, children have been considered fair game for the industry. ${ }^{110}$ Employment of jump boys to gain market share has been described as an "accepted practice"110 in the Philippines, where street vendors selling loose cigarettes are often children. ${ }^{114}$ These "mobile shops" are sometimes as young as six years of age. ${ }^{115}$ In 1994, it was noted that Marlboro and Philip Morris strengths were in urban areas supported by jumpboys, who made higher returns on PMI products due to high customer demand, brand loyalty, and retail pricing. ${ }^{12}$

When the jumpboy marketing tactic was exposed to the world, however, the tobacco companies denied any responsibility. The Far Eastern Economic Review featured a report entitled "Tomorrow's Marlboro Man," accompanied by a picture of "an eleven year old boy, cigarette dangling from his mouth, selling Marlboro in the middle of a Manila traffic jam". PMI Asia was apparently sensitive to this publicity and 
asked its New York headquarters for "ideas on how we can disseminate information regarding:

1) Our lack of control on jump boys,

2) Why they sell cigarettes on streets, i.e. gainful employment."116

Youth not only sold cigarettes, but were also considered in cigarette price structuring. To gain youth sales, the price of cigarettes was invariably reduced..$^{95} 117$ If price decreases were not viable, smaller or free sampling packs were implemented..$^{95}$ The Global Youth Tobacco Survey reported that more students aged less than 12 reported being offered "free" cigarettes than those of older ages. ${ }^{8}$ In the same year (2001), it was reported that $56 \%$ of children smoked. This represented a substantial rise from 1987 when $22 \%$ of children smoked. ${ }^{79}$

\section{Tobacco Regulation Act of 2003}

Apart from the above mentioned advertising and packaging regulations, the Tobacco Regulation Act of 2003 (Republic Act No. 9211) prohibits smoking in all public places, and prohibits tobacco sales within $100 \mathrm{~m}$ of schools, playgrounds, and other facilities frequented by youth. It requires retailers to demand proof of age from cigarette buyers, and display signs stating that it is an offence to sell cigarettes to persons under 18 years. All sponsorship shall be banned by 1 July 2008. Violators of this new Act will be fined between 500 pesos (about US\$10) to 400000 pesos (about US\$7,270) and can be imprisoned from 30 days to three years. ${ }^{118}$

Tobacco companies have prepared for these restrictions. For example, a British American Tobacco brand manager stated in 2004 that future marketing would be focused on one-to-one "permission marketing" in order to counter restrictions placed on mass media strategies. ${ }^{119}$ Here, consumers provide marketers with permission to send them promotional messages thus improving targeting precision. ${ }^{120}$ "Permission marketing allows us to talk to consumers on their level, on their turf". ${ }^{119}$

Further, the Republic Act No. 9211 mandated the creation of Inter-agency Committee-Tobacco (IAC-Tobacco). Its tasks have included the crafting of the implementing rules and regulations (IRR) of the said law and the subsequent exclusive power of administration and implementation. ${ }^{72}$ The IAC-Tobacco has nine members, including seven representatives from government agencies, one from the tobacco industry, and one from a non-government organisation. The National Tobacco Administration has a long history of pro-tobacco policy. The Department of Trade and Industry, which heads the IAC-Tobacco, has also been labelled as protobacco by anti-tobacco activists. The World Health Organization $^{121}$ has concluded that "Continuing efforts to enact comprehensive legislation have yet to achieve victory" in the Philippines.

\section{DISCUSSION}

The profile of tobacco control in Asia varies notably from Thailand, Singapore, and Hong Kong which have some of the world's leading policies, to nations at the other extreme such as the Philippines and Cambodia, which have a high smoking prevalence and weak controls. The Philippines has long been an unrestricted operating environment for tobacco companies, ripe for corruption and exploitation. Political cronyism was endemic for decades, allowing companies to capitalise on their marketing freedoms to the fullest potential in order to market their products to children younger than any segment hitherto revealed in tobacco industry document research. Women, children, youth, and the poor have been exploited over decades through countless marketing activities via

\section{What this paper adds}

This paper is the first to draw upon industry documents to overview and highlight the conduct of the tobacco industry in the Philippines since the 1960s. Drawing on industry documents, it reveals that the Philippines has long been considered by the tobacco industry as a laissez faire operating environment ripe for exploitation. Areas explored include political corruption, health, employment of consultants, resisting pack labelling, and marketing and advertising.

messages of hope, emancipation, sporting prowess, pop culture, and the emulation of western affluence. ETS consultants were employed to defend the industry's position and maintain the social acceptability of smoking. Political influence enabled companies to limit the effectiveness of bills relating to cigarette pack warnings, including tar and nicotine levels.

Against international standards of progress, the timetable for implementation of the Tobacco Act's provisions unfortunately locate the Philippines as among the world's slowest nations to take tobacco control seriously. The legacy of the industry's ability to exploit their commercial and political freedom remains today in the burgeoning growth in smoking by young Filipinos.

\section{Authors' affiliations}

K Alechnowicz, S Chapman, School of Public Health, University of Sydney, Sydney, NSW, Australia

Funding source: National Health \& Medical Research Council (Australia) \#153857. National Institutes of Health (USA) \#1 R01 CA87110-01A1

\section{REFERENCES}

1 Hemisphere Leo Burnett. Philip Morris Asia 1995 public relations plan. 1995. Philip Morris. Bates No. 2083463726/3727 http:// legacy.library.ucsf.edu/tid/naa65c00.

2 Hemisphere Leo Burnett. 1995 PR plan for the Philippines. 21 Nov 1994. Philip Morris. Bates No. 2083463721/3725 http://legacy.library.ucsf.edu/ $\mathrm{tid} /$ maa65 00 .

3 News article. The Philippines ranks first in PMl's Asia region. 1996. Philip Morris. Bates No. 2074417313 http://legacy.library.ucsf.edu/tid/ wks 17d00.

4 Altria. The Philip Morris International Story. 2004. http://www.altria.com/ about_altria/01_05_04_pmistory.asp [Accessed 7 Jul 2004].

5 Mallari DT. Philip Morris' new plant a smoking showcase. Philippine Daily Inquirer 13 Oct, 2002:10.

6 Mackay J, Eriksen M. The tobacco atlas. Geneva: World Health Organization, 2002.

7 World Bank. HNPStats. 2001. http://devdata.worldbank.org/hnpstats [Accessed 11 May 2004].

8 Miguel-Baquilod M. Report on the results of the National Youth Tobacco Survey in the Philippines GYTS 2000. Manila, Philippines: National Epidemiology Center, 2001.

9 Philippine Senate Committee on Health and Demography. A white paper on tobacco and smoking. 25 Oct 1999. Philip Morris. Bates No. 2075194995/ 5064 http://legacy.library.ucsf.edu/tid/xqq52c00.

10 Guindon GE, Tobin S, Yach D. Trends in affordability of cigarette prices: ample room for tax increases and related health gains. Tobacco Control 2002; 11:35-43.

11 Barnes JA. Management visit to Asia. 18 Apr 1995. R.J. Reynolds. Bates No. 513214462/4640 http://legacy.library.ucsf.edu/tid/jin30d00.

12 Pereira ADG. Philippines. 7 Jan 1994. British American Tobacco. Bates No. BAT500045818/5834 http://tobacco.health.usyd.edu.au/tds/ BAT500045818_5834 [Accessed 7 Jul 2004].

13 Shafey O, Dolwick S, Guindon GE, eds. Tobacco control country profiles, 2nd ed. Atlanta, Georgia: American Cancer Society, 2003.

14 Church P. A short history of Southeast Asia, Rev, ed. Singapore: John Wiley \& Sons (Asia) Pte Limited, 2003.

15 National Economic and Development Authority. Medium-term development plan 2001-2004. [2001]. http://www.neda.gov.ph/../ads/mtpdp/ mtpdp_partl.htm [Accessed 7 Jul 2004].

16 World Bank. Philippines at a glance. 2003. http://www.worldbank.org/ data/countrydata/aag/ph1_aag.pdf [Accessed 7 Jun 2004]. 
17 United Nations Development Programme. Philippine progress report on the Millennium Development Goals. 2000. http://www.undp.org/mdg/phil.pdf [Accessed 7 Jul 2004].

18 Philip Morris. [Report no. 6: Licensee and new development briefing of January 16, 1964]. 16 Jan 1964. Philip Morris. Bates No. 2012583036/ 3038 http://legacy.library.ucsf.edu/tid/agul 4e00.

19 Master Settlement Agreement websites. Philip Morris (http:// www.pmdocs.com), RJ Reynolds (http://www.rirtdocs.com), Lorillard (http://www.lorillarddocs.com), The Tobacco Institute (http:// www.tobaccoinstitute.com), The Council for Tobacco Research (http:// www.ctr-usa.org), Brown \& Williamson (http://www.bwdocs.com) and the American Tobacco Company (http://www.bwdocs.com).

20 Lee K, Gilmore AB, Collin J. Looking inside the tobacco industry: revealing insights from the Guildford Depository. Addiction 2004;99:394-7.

21 Kang DC. Crony capitalism: corruption and development in South Korea and the Philippines. Cambridge: Cambridge University Press, 2002.

22 Heymans J. [Letter no. 18 to G. Weissman and G. Dawson]. 5 Feb 1962. Philip Morris. Bates No. 2012582616/2622 http:// legacy.library.ucsf.edu/tid/mcb85e00.

23 Heymans J. Letter no. 6. 24 Jan 1963. Philip Morris. Bates No. $2012583131 / 3135 \mathrm{http}: / /$ legacy.library.ucsf.edu/tid/jqb85e00

24 Milhomme FP. Philippine field trip May 12-May 17, 1973. 11 Jun 1973. Lorillard. Bates No. 88730658/0665 http://www.lorillarddocs.com/PDF/ 88730658 0665.PDF [Accessed 10 Mar 2004].

25 Taylor M. Philippines. 24 Mar 1993. Brown \& Williamson. Bates No. 847210954 http://legacy.library.ucsf.edu/tid/ffe21c00.

26 Philip Morris. Leaf highlights. 2 Apr 1993. Philip Morris. Bates No. 2073701898/1900 http://legacy.library.ucsf.edu/tid/jre67c00.

27 Harris D. Philip Morris Asia three year plan 1994-1996. Dec 1993. Philip Morris. Bates No. 2073898386/8401 http://legacy.library.ucsf.edu/tid/ qra76c00.

28 Whist A. Philip Morris International Corporate Affairs. 17 Dec 1986. Philip Morris. Bates No. $2025431401 / 1406$ http://legacy.library.ucsf.edu/tid/ mir25e00.

29 Cicco MD. Journal of Commerce. Philippines opens big fight against business cartels. 4 Feb 1993. Philip Morris. Bates No. 2078274470B/4471 http:// legacy.library.ucsf.edu/tid/kfb70c00.

30 Association of Southeast Asian Nations. Southeast Asia A Free Trade Area ASEAN Secretariat. 2002. http://www. aseansec.org/viewpdf.asp?file=/ pdf/afta.pdf [Accessed 12 Aug 2004].

31 Johnson DP. Quarterly report-new products development domestic group. 4 Apr 1974. R.J. Reynolds. Bates No. 502802360/2375 http:// legacy.library.ucsf.edu/tid/crd78d00.

32 Taylor M. Comments on Philippine report. 9 Jul 1993. Brown \& Williamson. Bates No. $465494878 / 4879$ http://legacy.library.ucsf.edu/tid/swj90f00.

33 INFOTAB. Infodate: Third National Congress on Oncology (November 29, 1982) Manila-The Philippines. 8 Mar 1983. Brown \& Williamson. Bates No. $690821955 / 1963$ http://legacy.library.ucsf.edu/tid/ctk01f00

34 INFOTAB. [Infotopics summaries of public information: Philippine Journal of Oncology lung cancer issue]. $29 \mathrm{Apr}$ 1985. Council for Tobacco Research. Bates No. $10415282 / 5282$ http://legacy.library.ucsf.edu/tid/htq4aa00.

35 Cummings KM, Morley CP, Hyland A. Failed promises of the cigarette industry and its effect on consumer misperceptions about the health risks of smoking. Tobacco Control 2002;11(suppl I):i110-17.

36 Tofler A, Chapman S. "Some convincing arguments to pass back to nervous customers": the role of the tobacco retailer in the Australian tobacco industry's smoker reassurance campaign 1950-1978. Tobacco Control 2003;12(suppl III):iii7-12.

37 Carter SM, Chapman S. Smoking, disease, and obdurate denial: the Australian tobacco industry in the 1980s. Tobacco Control 2003;12(suppl III):iii23-30.

38 O'Sullivan B, Chapman S. Eyes on the prize: transnational tobacco companies in China 1976-1997. Tobacco Control 2000;9:292-302.

39 Tobacco Reporter. WHO hits at tobacco again in report seeking worldwide legal action to "protect" nonsmokers. 1975. R.J. Reynolds. Bates No. 500324352/4353 http://legacy.library.ucsf.edu/tid/zfz79d00.

40 Rotary Club of Quezon City. Quezoniana. 12 Dec 1975. Lorillard. Bates No. 03746429/6430 http://legacy.library.ucsf.edu/tid/wlr40e00.

41 Bulletin Today. 'Lower' cancer risk in Pinoys? 22 Dec 1975. Lorillard. Bates No. 03746424 http://legacy.library.ucsf.edu/tid/slr40e00.

42 Times Journal. New light shed on smoking perils. $18 \mathrm{Dec}$ 1975. Philip Morris. Bates No. 2010046329 http://legacy.library.ucsf.edu/tid/ zlx61f00.

43 Philippines Daily Express. Doctor debunks link of smoking to hypertension. 19 Dec 1975. Philip Morris. Bates No. 2010046325 http:// legacy. library.ucsf.edu/tid/vlx61fo0.

44 Greenspan, Yelon PC. Jacob and Medinger special account \#4, February 29, 1976. 29 Feb 1976. American Tobacco Company. Bates No. $955007577 / 7579$ http://legacy.library.ucsf.edu/tid/lpl41 a00.

45 Philippine Virginia Tobacco Administration. [Smoking and Health Forum] Oct 1984. Philip Morris. Bates No. 2504062304/2346 http:// legacy.library.ucsf.edu/tid/jnw32e00.

46 Kyle T. [Letter to D.S. Devitre]. 7 Aug 1975. Philip Morris. Bates No. 1000219960/9961 http://legacy.library.ucsf.edu/tid/wce84e00.

47 Republic of the Philippines Department of Health National Cancer Control Center Manila. [Cigarette analysis]. Aug 1975. Philip Morris. Bates No. 1005135546/5547 http://legacy.library.ucsf.edu/tid/fxk28e00.

48 Philippine Tobacco Board. [Advertisement]. 1975. Lorillard. Bates No. $01586912 \mathrm{http}: / /$ legacy.library.ucsf.edu/tid/vfg51e00.
49 Devitre DS. Tar \& nicotine reduction in the Philippines. 16 Apr 1981. Philip Morris. Bates No. $2074893871 / 3872$ http://legacy.library.ucsf.edu/tid/ fay 17 d00.

50 Muggli ME, Hurt RD, Blanke DD. Science for hire: a tobacco industry strategy to influence public opinion on secondhand smoke. Nicotine Tob Res 2003;5:303-14

51 Hiilamo $\mathbf{H}$. Tobacco industry strategy to undermine tobacco control in Finland. Tobacco Control 2003;12:414-23.

52 Barnoya J, Glantz S. Tobacco industry success in preventing regulation of secondhand smoke in Latin America: the "Latin Project". Tobacco Control 2002;11:305-14.

53 Assunta M, Fields N, Knight J, et al. "Care and feeding": The Asian environmental tobacco smoke consultants programme. Tobacco Control 2004;13(suppl II):ii4-12.

54 Billings DM, Rupp JP. Asia ETS consultants status report. 14 Feb 1990. Philip Morris. Bates No. 2500048976/8998 http://legacy.library.ucsf.edu/tid/ zzd58d00.

55 Philip Morris Asia. Corporate Affairs Plan 1990-1992. Dec 1989. Philip Morris. Bates No. $2500084000 / 4042$ http://legacy.library.ucsf.edu/tid/ lil19e00.

56 So SV. Asia ETS consultants project. 25 Feb 1989. Philip Morris. Bates No. 2500048655/8662 http://legacy.library.ucsf.edu/tid/vzf87e00.

57 Billings DM. ETS project update. 10 Apr 1989. Philip Morris. Bates No. 2500048643/8654 http://legacy.library.ucsf.edu/tid/uzf87e00.

58 Billings DM, Rupp JP. Asia ETS project: status report. 27 Sep 1989. Philip Morris. Bates No. 2500048508/8515 http://legacy.library.ucsf.edu/tid/ kzf87e00

59 Philippine Daily Inquirer. Poor ventilation, not tobacco smoke, is culprit for indoor pollution-study. 23 Mar 1996. Philip Morris. Bates No. 2048549733 http://legacy.library.ucsf.edu/tid/iqc57d00.

60 Anon. Philippines eyes health warning. Tobacco Reporter 1972;99(4)Apr:50-2.

61 Anon. Warning on cigarette packages urged. Tobacco Reporter $1981 ; 108(11)$ Nov: 24 .

62 INFOTAB. Smoking issues status book. Aug 1983. Philip Morris. Bates No. 2028348096/8417 http://legacy.library.ucsf.edu/tid/byd24e00.

63 Chilcote SD. Tobacco Institute. Exhibit A warning label requirements and advertising and promotion restrictions in Japan, South Korea, Taiwan, Hong Kong, China, Philippines, Indonesia, Belgium, Saudi Arabia and Singapore: [attachment to letter sent to Congressman T.A. Luken]. 1 Jul 1988. Lorillard. Bates No. $87703119 / 3130$ http://legacy.library.ucsf.edu/tid/rqn2le00.

64 Anon. Public hearing brings out all sides of tobacco debate. Tobacco Reporter 1988;115(4)Apr:12-13.

65 Harris D. [Email to M. Winokur]. 17 Dec 1991. Philip Morris. Bates No. 2500115497 http://legacy.library.ucsf.edu/tid/fsy7lc00

66 Rilev D. PMI corporate affairs weekly highlights; December 13-17, 1993 22 Dec 1993. Philip Morris. Bates No. 2500064857/4862 http:// legacy.library.ucsf.edu/tid/jhf42e00

67 Corrao MA, Guindon GE, Sharma N, et al. eds. Tobacco control country profiles. Atlanta, Georgia: The American Cancer Society, 2000.

68 Republic of the Philippines. Republic act no. 7394: the Consumer Act of the Philippines. 1992. http://www.chanrobles.com/republicactno7394.htm [Accessed 30 Aug 2004]

69 Hulit M. Marketing issues corporate affairs conference May 27, 1994Manila. 27 May 1994. Philip Morris. Bates No. 2504015017/5042 http:// legacy.library.ucsf.edu/tid/iga42e00.

70 Pollak L. Highlights week ending February 6, 1994. 7 Feb 1994. Philip Morris. Bates No. 2073950843 http://legacy.library.ucsf.edu/tid/ npt45c00.

71 Republic of the Philippines Regional Trial Court. [Philippine Tobacco Institute, plaintiff, vs Secretary of Health Juan M. Flavier, defendant]. 1 Feb 1994. Philip Morris. Bates No. $2023246851 / 6863 \mathrm{http}: / /$ legacy.library.ucsf.edu/tid/duu34e00

72 Republic of the Philippines. Republic act no. 9211: an act regulating the packaging, use, sale, distribution and advertisements of tobacco products and for other purposes, 2002. hittp://www.congress.gov.ph/download/ra/ RA09211.pdf [Accessed 12 Jul 2004]

73 World Health Organization. Tobacco or Health: A global status report. Geneva: World Health Organization, 1997.

74 Markar-Macan M. Tobacco wars: Singapore the picture of health. Asia Times Online 5 Sep 2003. http://www.atimes.com/atimes/ Southeast_Asia/EI05Ae02.html [Accessed 30 Aug 2004].

75 Blanke DD, ed. Tobacco control legislation: an introductory guide. Geneva: World Health Organization, 2003.

76 Anon. Lord brand in the Philippines. Tobacco Reporter 1973;100(2)Feb:52.

77 Simpson D. Philippines: sacred and profane. Tobacco Control $2001 ; 10: 204-9$

78 Honan M. Mojo Wire. Holy Smoke!: the Virgin Mary was a Marlboro woman - and other outrageous tactics big tobacco uses to sell cigarettes abroad, 23 Jul 1998. Philip Morris. Bates No. 2072522565/2567 http:// legacy.library.ucsf.edu/tid/gva06c00.

79 Kaufman N, Nichter M. The marketing of tobacco to women: global perspectives. In: Samet J, Yoon S-Y, eds. Women and the tobacco epidemic: challenges for the 21 st century. Geneva: World Health Organization in collaboration with the Institute for Global Tobacco Control, Johns Hopkins School of Public Health, 2001:69-98.

80 Anon. Sweepstakes give-aways promote cigarettes. Tobacco Reporter 1983;110(8)Aug:70.

81 Anon. Seven Stars Lights sports new look. Tobacco Reporter 1989;116(2)Feb:36. 
82 Morrow M, Barraclough S. Tobacco control and gender in Southeast Asia Part I: Malaysia and the Philippines. Health Promotion International 2003; 18:255-64.

83 Maximo Y. Tobacco. World news. 1971. American Tobacco Company. Bates No. 950306480/6500 http://legacy.library.ucsf.edu/tid/phj34f00

84 Mason W. Trip report-Manila, July 10-14, 1983. 18 Jul 1983. Brown \& Williamson. Bates No. $621604739 / 4741$ http://legacy.library.ucsf.edu/ tid/Irh90f00

85 World Health Organization. Report of a WHO Workshop on Smoking and Health Issues in Developing Countries Colombo, Sri Lanka, 18-20 November 1981. 1982. Philip Morris. Bates No. 1002972380/2390 http:// legacy.library.ucsf.edu/tid/ibd18e00.

86 Raymundo CM, Cruz GT. Dangerous connections: substance abuse, sex and risk behaviors among Filipino adolescents. 2003. http:// www.childprotection.org.ph/monthlyfeatures/archives/apr2k4a.doc [Accessed 12 Jul 2004].

87 Wu C. [Virginia Slims ad concept/product (1 stick) test: executive summary attachment sent to PM executives]. Mar 1993. Philip Morris. Bates No. $2504052734 \mathrm{http}: / /$ legacy.library.ucsf.edu/tid/rlv19e00.

88 Anon. Recent Philippine launches. Tobacco Reporter 1976;103(2)Feb:59.

89 Pittman RA. [Memo to J.A. Broughton et al. concerning marketing descriptors for the young smokers segment]. 24 Jan 1975. Brown \& Williamson. Bates No. 670192436 http://legacy.library.ucsf.edu/tid/ jwd14f00.

90 Mason W. Philippines-9/18-9/24. 26 Sep 1983. Brown \& Williamson. Bates No. $621604731 / 4733$ http://legacy.library.ucsf.edu/tid/krh90fo0.

91 Mason W. Trip report-Manila, Philippines. 13 Sep 1984. Brown \& Williamson. Bates No. 620446932/6935 http://legacy.library.ucsf.edu/ $\mathrm{rid} / \mathrm{fzb} 31 \mathrm{fOO}$.

92 Connolly GN. American Cancer Society. Testimony of Gregory N. Connolly, D.M.D., M.P.H. on behalf of the American Cancer Society before the U.S. Trade Representative on Section 301-Thailand September 19, 1989. 19 Sep 1989. Philip Morris. Bates No. $2500077388 / 7400$ http:// legacy.library.ucsf.edu/tid/wze42e00.

93 Philippine Tobacco Institute. Voluntary code for the marketing of cigarettes. 3 Feb 1991. Philip Morris. Bates No. 2504064066/4071 http:// legacy.library.ucsf.edu/tid/uxv19e00.

94 RJ Reynolds Tobacco International. Business plan. 1993. R.J. Reynolds. Bates No. 51 1400580/0793 http://legacy.library.ucsf.edu/ tid/iby43d00.

95 Philip Morris. Philippines 1993 Brand Plans. 1993. Philip Morris. Bates No. 2504006958/7023 http://legacy.library.ucsf.edu/tid/sdq19e00.

96 Zaldivar V. Philippine consumption rate increasing $20 \%$ annually. Tobacco Reporter 1971;98(11)Nov:24.

97 Knight J, Chapman S. "Asian yuppies... are always looking for something new and different": creating a tobacco culture among young Asians. Tobacco Control 2004;13(suppl II):ii22-9.

98 Philip Morris International. PMI statement on prevention of youth access to cigarettes. 18 Dec 1997. Philip Morris. Bates No. 2073563052/3074A http://legacy.library.ucsf.edu/tid/fac95c00.

99 Philip Morris. Corporate Affairs. 1999. Philip Morris. Bates No. 2074188556/8612 http://legacy.library.ucsf.edu/tid/sgk45c00

100 Philip Morris. Selected youth no-smoking general education programs. 1998. Philip Morris. Bates No. 2072908669 http:// legacy.library.ucsf.edu/tid/itt27d00.

101 Anon. Philippine activities. Tobacco Reporter 1974;101(9)Sep:84.
102 Philip Morris Asia Inc. Five year plan 1981-1985. Nov 1980. Philip Morris. Bates No. 2504017362/7424 http://legacy.library.ucsf.edu/tid/ tux32e00.

103 Philip Morris Asia Inc. Formula One evaluation: Philippines. May 1993. Philip Morris. Bates No. 2504052837/2839 http:// legacy.library.ucsf.edu/tid/vix32e00.

104 Villasis O. Philippine consumption continues to gain. Tobacco Reporter 1972:99(11)Nov:52-4

105 Anon. Martial law 'stops' smuggling. Tobacco Reporter 1973;100(11)Nov: 25, 61 .

106 Anon. Marlboro game promotion in the Philippines. Tobacco Reporter 1973;100(8)Aug:58, 60

107 INFACT. Tobacco marketing to young people. Mar 1994. Philip Morris. Bates No. 2073953663/3664 http://legacy.library.ucsf.edu/tid/ vrs $45 \mathrm{c} 00$

108 Felicano I. Two SEG project proposals for Philip Morris Asia. 24 Nov 1988. Philip Morris. Bates No. 2504054137/4139 http:// legacy.library.ucsf.edu/tid/zvi81c00.

109 News article. Basketball scores big win in the Philippines. Apr 1994. Philip Morris. Bates No. 2505628914 http://legacy.library.ucsf.edu/tid/ $\mathrm{ntf} 25 \mathrm{c} 00$.

110 Sessers S. New Yorkers magazine. A reporter at large: Opium War redux. 13 Sep 1993. Philip Morris. Bates No. 2500051020/1030 http:// legacy.library.ucsf.edu/tid/fdf42e00.

111 Roberto E. Consumer Pulse Inc. Project BWK and Project "Count K". 8 May 1981. Brown \& Williamson. Bates No. $620675245 / 5266 \mathrm{http}: / /$ legacy.library.ucsf.edu/tid/tbd61 foo.

112 Causey R. Target market profile study-Philippines (83-46). 8 Feb 1984. Brown \& Williamson. Bates No. $465261690 / 1694 \mathrm{http}: / /$ legacy.library.ucsf.edu/tid/hxn01 foO.

113 Lok H. Philippines Marlboro Lights tracking study. 2 Mar 1988. Philip Morris. Bates No. $2504054667 / 4682$ http://legacy.library.ucsf.edu/tid/ jhy32e00.

114 Mongoven Biscoe \& Duchin Inc. Countries' standings at WHO. May 1995. Philip Morris. Bates No. 2081248277/8409 http:// legacy.library.ucsf.edu/tid/ifg30c00

115 Chapman S. Philippines: poverty, powerlessness, and Our Lady of Cigarettes. Tobacco Control 1994;3:200-7.

116 Rekart P. Juvenile smoking in the Asia region. 22 Jan 1990. Philip Morris. Bates No. 2504042071/2072 http://legacy.library.ucsf.edu/tid/ snw19e00.

117 Chaloupka FJ, Cummings KM, Morley CP, et al. Tax, price and cigarette smoking: evidence from the tobacco documents and implications for tobacco company marketing strategies. Tobacco Control 2002;11(suppl I):i62-72.

118 Xinhua News Agency. Philippines to implement Tobacco Regulation Act in 2004. Xinhua News Agency 19 Dec 2003. http://brownw.newsreal.com [Accessed 20 Dec 2003]

119 Yap KLM. Tobacco companies are prepared. BusinessWorld. (Manila, Philippines) 5 Mar 2004:26. http://codex.bworldonline.com [Accessed 9 Mar 2004].

120 Krishnamurthy S. A comprehensive analysis of permission marketing Journal of Computer-Mediated Communication 2001;6(2). http:// www.ascusc.org/jcmc/vol6/issue2/krishnamurthy.html. [12 Aug 2004].

121 World Health Organization. Tobacco control legislation: an introductory guide, 2nd ed. Geneva: World Health Organization, 2004. 